\title{
CHOICE OF THE ACETABULAR COMPONENT PLACEMENT IN DYSPLASTIC HIP PATIENTS
}

\author{
Silvestris Zēbolds ${ }^{1,2, \#}$, Aigars Pētersons ${ }^{1}$, and Andris Jumtiņš ${ }^{1}$ \\ ${ }^{1}$ Rīga Stradinš University, 16 Dzirciema Str., Rīga, LV-1007, LATVIA \\ 2 Hospital of Traumatology and Orthopaedics, 22 Duntes Str., Rīga, LV-1005, LATVIA \\ \# Corresponding author, szebolds@apollo.Iv
}

Contributed by Aigars Pētersons

\begin{abstract}
Total hip arthroplasty (THA) in patients with hip dysplasia is a challenging surgical operation. Many orthopedic surgeons concur that the anatomical placement of the acetabular components of endoprostheses (AC-EPS) during THA yields the best result. However, there are advocates of the high rotation center of the hip joint after replacement surgery. In our study, we compared the outcomes of THA based on the placement of acetabular cups to identify the most favorable site for AC-EPs in patients with varying grades of dysplastic osteoarthritis. Our study included 88 patients with dysplastic hip osteoarthritis who underwent 106 THAs during a three-year period using cementless fixation endoprostheses. Functional results were assessed by Merle d'Aubigne and Postel's method and by instrumental gait analysis (IGA). Gait deviation index was calculated based on IGA to compare results in different acetabular component placement groups. Functional assessment of patients by Merle d'Aubigne and Postel's grading method and IGA showed no significant difference in results due to the placement of the acetabular component. Most complications were found in the severe dysplasia patients group with the anatomical placement of the $A C$-EP. The appropriate location of cementless acetabular cups during THA in dysplastic hips depends on the grade of dysplasia, expected elongation of the leg, and the potential for adequate bone coverage for the AC-EP. In cases of severe dysplasia, the placement of the AC-EP in the secondary socket can provide a good functional outcome and reduce the risk of complications.
\end{abstract}

Key words: hip osteoarthritis, hip arthroplasty, hip replacement, developmental dysplasia of the hip, surgical technique.

\section{INTRODUCTION}

Patients with osteoarthritic hip dysplasia can experience an underdeveloped hip joint socket, resulting in a shallow and elongated socket structure preventing the femoral head from making full contact with the articular surface of the joint. The bones of the pelvis often lack the mass necessary for the stable insertion of the acetabular component of an endoprosthesis (AC-EP). Due to these pronounced anatomical changes, hip arthroplasty in patients with dysplastic osteoarthritis (OA) is considered a complicated surgical operation (OP) (Crowe et al., 1979; Henrich et al., 2007; Park et al., 2007; Shen et al., 2009; Kärrholm et al., 2015; Helkemaa et al., 2016) with a considerably higher risk of complications compared to patients with degenerative OA. Many authors believe that during THA, it is advisable to position the AC-EP in the primary joint socket (Charnley, 1979; Lund and Tennansen, 1985; Symeonides et al., 1997; Bi- canic et al., 2009), thus positioning the hip rotation center at the level of the anatomical joint socket center. According to these authors, the EP's anatomical positioning ensures the proper functioning of the gluteal muscles, allowing walking without pronounced limping. Others like Montalti et al. (2018) argue that the AC-EP can be inserted into the joint's secondary socket. Harris et al. (1998) and Bozic et al. (2004) have the same opinion regarding very serious cases of dysplasia. However, integrated studies about the placement of the AC-EP (in the primary or secondary joint's socket), the grade of dysplasia, and the potential risk of intra- and postoperative complications must be continued. To achieve the best possible replacement surgery results, it is necessary to develop precise criteria for the choice of placement of the AC-EP.

The hypothesis of our study was that a good clinical and functional result in patients with dysplastic OA can be 
achieved by placing the AC-EP in the secondary joint's socket during THA.

The purpose of the study was to analyse and compare the radiological, clinical, and functional results of THA in dysplastic hips based on the placement of the acetabular components and to identify the most suitable placement of acetabular components in patients with varying grades of dysplastic OA.

\section{MATERIALS AND METHODS}

The study was conducted in the Hospital of Traumatology and Orthopaedics (HTO) and the Gait Analysis Cabinet of National Rehabilitation Centre "Vaivari". This retrospective study included 88 patients with hospitalisation diagnosis of dysplastic hip OA. Patients underwent 106 total hip replacement OPs (bilateral replacement for 18 patients) in HTO. The average age of patients was 44 years [range, 20 to 78 years]: 71 women [80.7\%] and 17 men [19.3\%]. In 80 [75.5\%] cases acetabular component of EP was placed in the primary socket of the joint, and in 26 [24.5\%] cases - in the secondary socket. All operations were performed between 2008 and 2011. The mean follow-up period after THA was 42 months (range, 24 to 60 months).

All patients gave written consent to participate in the study. Cementless fixation endoprostheses were used for all patients. The study did not include patients with other musculo-skeletal apparatus disorders affecting mobility, patients with decompensated cardiovascular diseases, or acute or chronic cerebrovascular disorders. Patients who had received treatment with cemented or hybrid type fixation endoprostheses were excluded. Three groups (one control and two study groups) were created based on the grade of dysplasia according to Crowe's classification (Crowe et al., 1979) and the placement of the AC-EP during surgery (i.e. in the joint's primary or secondary socket). The distribution of joints according to grade of dysplasia for each group is presented in Figure 1.

The control group (K1) included 47 cases with the lowest grade hip dysplasia (Crowe's classification grade I before surgery). The acetabular components of the EPs were placed in the primary (anatomical) joint socket for the K1 group, which consisted of 37 cases $(78.7 \%)$ in female patients and 10 cases $(21.3 \%)$ in male patients. The average

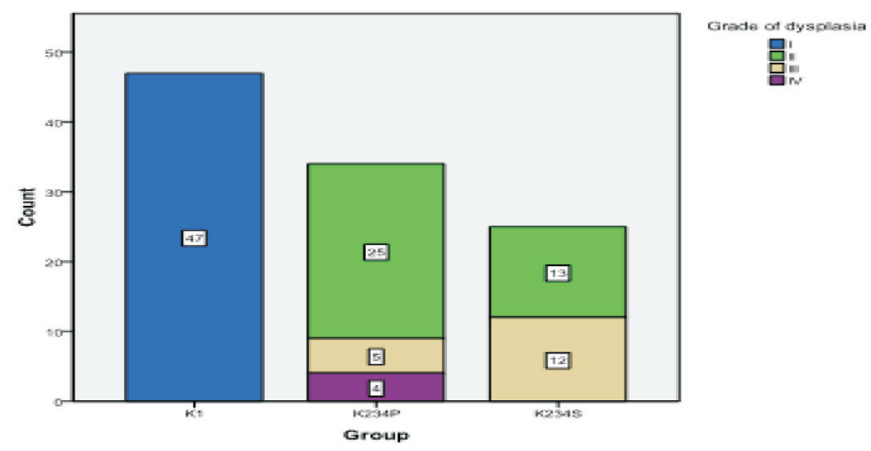

Fig. 1. Distribution of joints according to grade of dysplasia in each group. patient age was 43 years (range, 20 to 59 years). Patients in the $\mathrm{K} 1$ group received surgical techniques identical to those used for the degenerative OA patient groups.

The study groups included patients with severe hip joint dysplasia (Crowe grades II, III, or IV before surgery). The acetabular components of the EPs were placed in the joint's primary socket in the K234P group, which contained 34 cases of severe hip joint dysplasia: 27 cases $(79.4 \%)$ in female patients and 7 cases $(20.6 \%)$ in male patients. The average patient age in the K234P group was 47 years (range, 33 to 78 years).

The acetabular components of the EPs were placed in the joint's secondary socket for patients in the K234S group, which contained 25 cases of hip joint dysplasia (Crowe grade II or III before surgery): 23 cases $(92.0 \%)$ in female patients and 2 cases $(8.0 \%)$ in male patients. The average patient age in the K234S group was 45 years (range, 33 to 78 years).

For all groups, the average male/female ratio was $1: 4$. For the preoperative radiographic evaluation of patients, an anteroposterior (AP) X-ray of the pelvis and lateral (LL) Xray of the operable hip joint were obtained. The same radiographic investigations were carried out on the third postoperative day, and 3 and 12 months after surgery, and later according to the surgeon's discretion - once a year or in two years. All pre- and postoperative radiographic measurements were performed digitally using the orthopedic computer software AGFA Orthopaedic Tools (Figs. 2 and 3).

A 25-mm metallic ball marker was used for image calibration. Radiographs were obtained in Digital Imaging and Communications in Medicine format with the help of phosphorus plates and entered into the AGFA IMPAX archive. The reference point was set to be the joint's rotation center (RC). The hip joint's rotation center is the center of the femoral head before the surgery and the center of the EP head after surgery. If the RC (in AP projection) coincides with the anatomical acetabular socket's center after surgery, the AC-EP is considered to be inserted into the primary (anatomical) joint socket. The criterion chosen by us was as follows: if the hip joint's RC deviation cranially was 10 $\mathrm{mm}$, its position was considered consistent with the primary acetabular socket. If the hip joint's RC after surgery was shifted cranially $>10 \mathrm{~mm}$, the AC-EP was considered fixed in the secondary socket.

The center edge angle (CEA) metric - a specific characteristic of the coverage of the AC-EP - was created for this study (Fig. 3). If, after the OP, the CEA in a radiograph's AP projection was $<17^{\circ}$, the coverage of the AC-EP is considered not sufficient and a loosening of the AC-EP could be anticipated earlier than normal. The invention was awarded Latvian Patent No. 14412 (publication date, 20.01.2012).

We used Merle d'Aubigne and Postel's method for the functional assessment of patients (Merle d'Aubigne and Postel). The maximum total number of points against all 


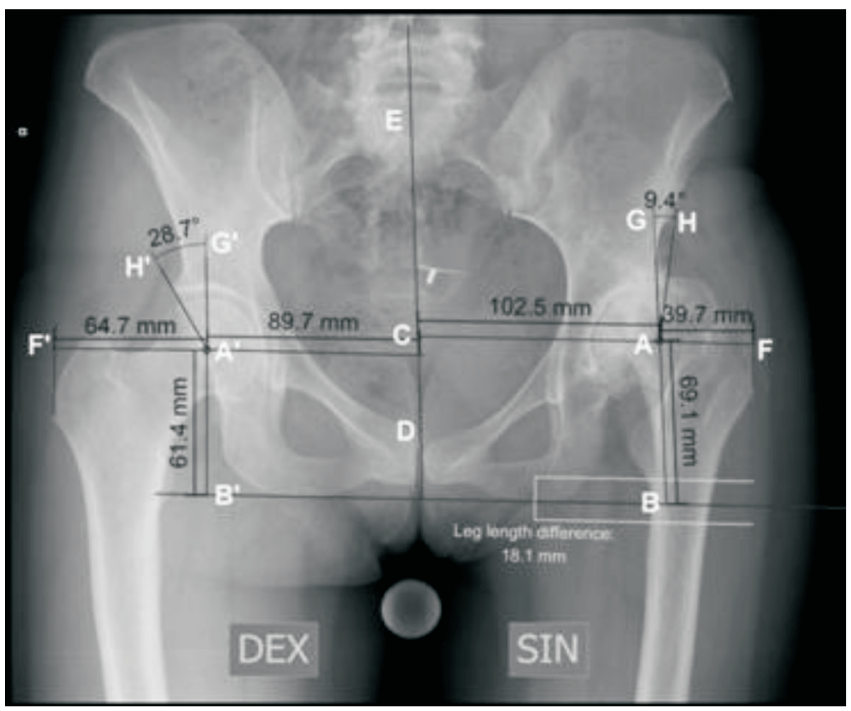

Fig. 2. Preoperative digital radiographic measurements. $\mathrm{AB}$, vertical location of the rotation center of the hip (VRC), the distance between the line connecting both ischial tuberosities and the center of the femoral head (or the center of the head of the endoprosthesis after surgery); AC, horizontal location of the rotation center of the hip (HRC), the distance between the center line (connecting the pubic symphysis and processus spinosus of the lumbar spine) and the center of the femoral head (or the center of the head of the endoprosthesis after surgery); $\mathrm{AF}$, offset, the distance between the center of the femoral head (or the center of the head of the endoprosthesis after surgery) and the lateral edge of the greater trochanter; GAH, Wiberg's lateral center-edge angle (LCEA), the angle between a vertical line drawn from the center of the femoral head and the line connecting the center of the femoral head with the top lateral edge of the acetabulum. A discrepancy of leg lengths is measured comparing the distances from the lower edge of both minor trochanters to the line connecting both ischial tuberosities.

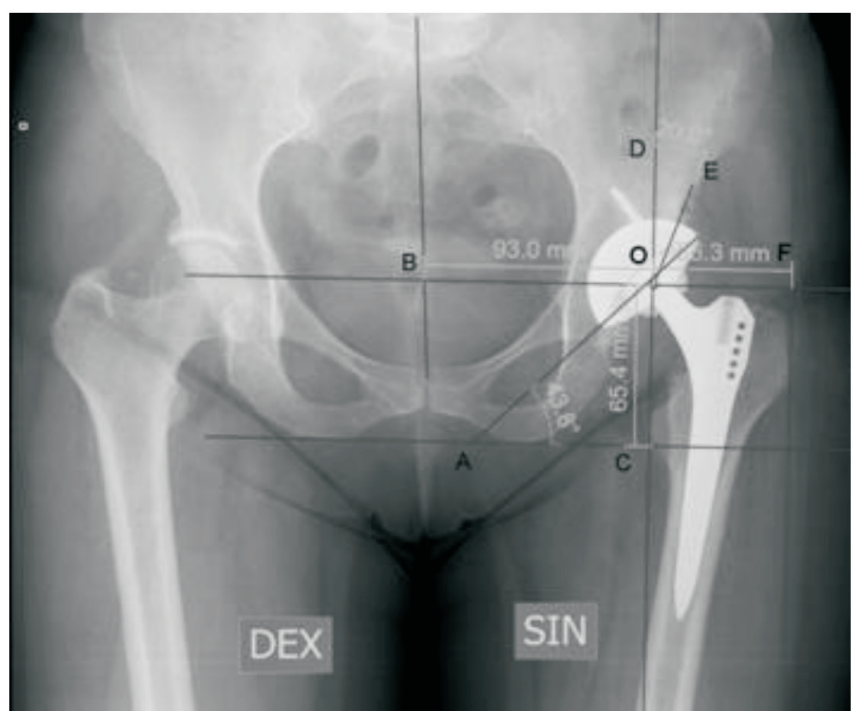

Fig. 3. Postoperative digital radiographic measurements. OAC, the inclination angle of the acetabular component in the pelvis; OC, the vertical location of the rotation center (VRC); OB, the horizontal location of the rotation center (HRC); OF, offset; DOE, the center edge angle (CEA).

criteria (pain, range of hip motion, and ability to walk with or without walking aids) is 18 , which corresponds to a healthy man. We assessed clinical outcomes before surgery and not earlier than one year after surgery. Instrumental gait analysis (IGA) was also performed. During IGA, quantitative information on the individual patient's body segment's relative motion during walking was collected. Six simultaneous infrared digital video cameras $(240 \mathrm{~Hz}$ Pro Reflex system cameras, made in Qualisys Medical company, Sweden) recorded gait via body-mounted marker coordinates, calculating movement trajectory. By processing the data with special gait analysis software (Visual 3D, C-motion Inc., USA), large joint movements of the lower limbs during walking were depicted as curves in all three planes simultaneously. Useful data for the research were recorded in a special protocol.

To compare the obtained results with normal gait indicators, another control group (K0) was established. K0 included 15 people who underwent IGA without musculoskeletal apparatus diseases or injury consequences that would affect movement. The results were compared with the IGA data of dysplastic OA patients after replacement surgery (IGA was performed not earlier than 1 year after the surgery).

For a comparison of the results, a gait deviation index (GDI) was calculated based on kinematic data from gait analysis using nine variables: pelvis and hip joint angles in three planes, knee joints in the sagittal plane (flexion/extension), ankle joints in sagittal plane (dorsiflexion/plantarflexion), and the foot progression angle in the $\mathrm{Y}$ plane. GDI provides a general description of gait abnormality and yields a single figure indicating how an individual's gait deviates from the average normal model. We used the index to measure gait and to assess the effectiveness of the THA and rehabilitation activities in different study groups.

Statistics. The Smirnov-Kolmogorov test was used to check the normality of pre- and postoperative measurements. Normally distributed data were analysed awith an ANOVA test. A Kruskal-Wallis test was used for non-normally distributed data. Hypotheses were checked at significance level $p=0.05$.

\section{RESULTS}

Radiographic results. The most important radiographic postoperative measurements were the CEA and offset. CEA after OP averaged $28.27^{\circ}$. Comparing this angle with Wiberg's LCEA before OP $\left(13.75^{\circ}\right)$, we can ascertain the AC-EP's coverage by bone after the OP in relation to the femoral head's coverage before the OP. The average coverage (relative to the hip joint's rotation center) increased by $14.52^{\circ}$.

To assess whether the increase of the CEA after the OP was statistically significant, a t-test was used for before and after OP results. Test results showed a statistically significant $(p<0.001)$ increase in average CEA after the OP (Fig. 4)

Postoperative average CEA value differences between groups were not statistically significant $(p=0.186)$.

Offset values after the OP increased. T-test results revealed that the average offset value increase was statistically significant $(p<0.001)$ in all groups. 


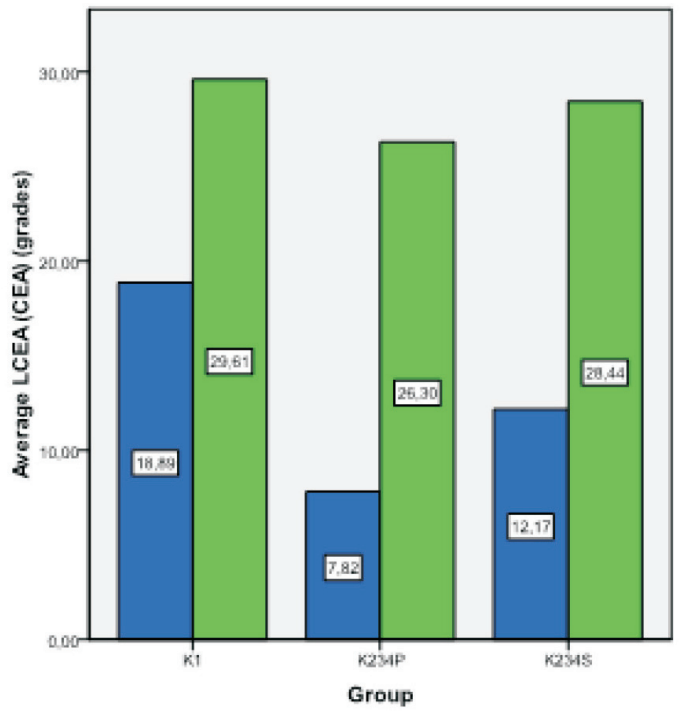
Preoperative
postoperative DPeceerative

Fig. 4. Lateral center-edge angle (LCEA) preoperatively in relation to the center edge angle (CEA) postoperatively in the control and study groups.

On average, the AC-EP's inclination angle in the pelvis was $40.96^{\circ}$ (K1, 40.83; K234P, 41.86 ${ }^{\circ}$ K234S, 39.99).

The average AC-EP size (outer diameter) was $52.95 \mathrm{~mm}$ (range, 46 to $64 \mathrm{~mm}$; K1, $53.23 \mathrm{~mm}$; K234P, $53.03 \mathrm{~mm}$; K234S, $52.32 \mathrm{~mm}$ ).

Functional outcome. The obtained results using the Merle d'Aubigne-Postel's Score for all of the scales showed statistically significant positive effect $(p<0.001$, Wilcoxon pairs test) for OPs. The assessments in groups with different grades of dysplasia did not significantly differ between groups ( $p=0.228$, Kruskal-Wallis test) (Fig. 5).

Instrumental gait analysis. IGA was performed for 28 patients ( 22 women, 6 men, average age, 46 years [range, 28 to 63 years]) who underwent 37 total hip replacements (9 patients bilaterally) due to dysplastic OA.

Joint (IGA records) distribution after THA among the groups was as follows: K1, 17 joints; K234P, 12 joints; K234S, 8 joints; and K0, 30 joints.

One or more years after THA, the average values of the parameters from all replaced joint groups (K1, K234P, and $\mathrm{K} 234 \mathrm{~S}$ ) were compared with gait analysis parameters of the non-operated control group (K0). In the OP groups, the average value of the support phase was longer, and amounted to $64.18 \%$ of the gait cycle time versus $62.13 \%$ in the $\mathrm{K} 0$ group. The swing phase, conversely, was longer in the $\mathrm{K} 0$ group $(37.87 \%)$ compared to the THA groups $(35.82 \%)$. The total range of hip motion in the swing phase in the sagittal plane was $30.47^{\circ}$ in the THA groups and $39.78^{\circ}$ in the K0 group. The average maximal hip flexion and extension in the sagittal plane in swing phase was $34.51^{\circ}$ for the THA groups and $30.47^{\circ}$ for the K0 group. Conversely, at the end of the support phase, the $\mathrm{K} 0$ group had a maximum extension of $8.32^{\circ}$, whereas the THA groups had a $4.04^{\circ}$ maximum extension (i.e. the hip joint stayed in flexion, not

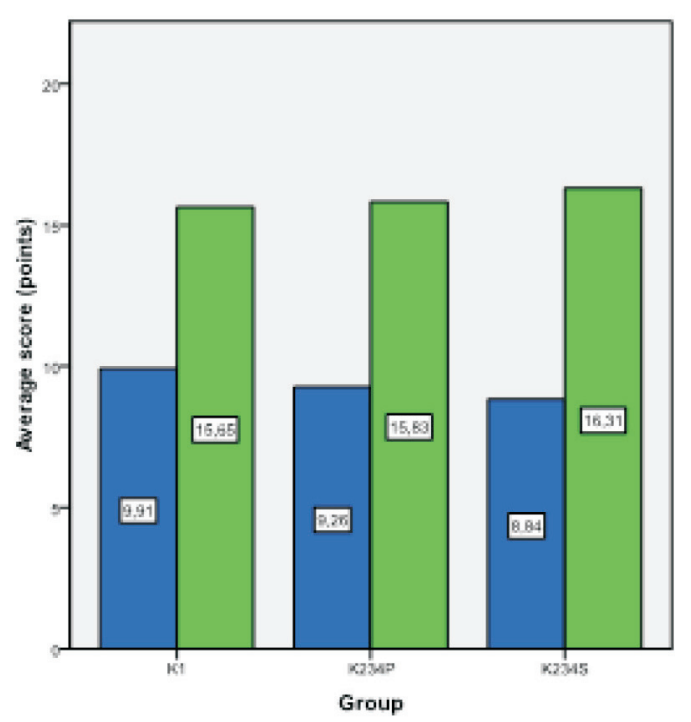

Preperathe, postopensation 品 Provosidive

Fig. 5. Overall functional assessment of patients before and after surgery (by Merle d'Aubigne and Postel's method) in the control and study groups.

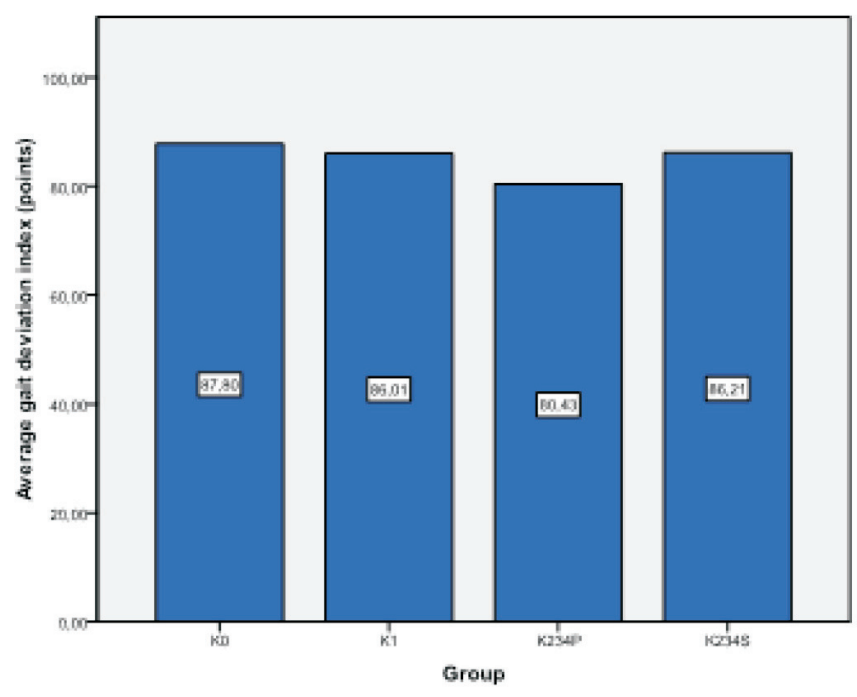

Fig. 6. Average GDI in each of the investigated groups.

reaching the extension position). The average range of motion of the pelvis in the sagittal plane was $5.38^{\circ}$ for the THA groups and $2.69^{\circ}$ for the K0 group. Minimum flexion (maximum extension) in the support phase of the knee joints was $9.8^{\circ} \pm 8.6^{\circ}$ for the THA groups and $6.4^{\circ} \pm 5.7^{\circ}$ for the K0 group. The comparison of IGA in all THA groups (K1, K234P, and K234S) with non-operated individuals group (K0) is presented as a GDI in Figure 6.

To assess whether average GDI was statistically significantly different across groups, a standard ANOVA test was performed (GDI was a normally distributed parameter). The difference in average GDI values between groups was not statistically significant $(p=0.235$; the current amount of data was not sufficient to demonstrate the opposite).

Complications. Of the 106 total hip replacements, 10 major complications developed (i.e. impacting patient rehabilitation time and quality of life). Seven of those major compli- 
cations were bone fractures observed, two complications were nerve damage-related, and one consisted of pronounced resorption (osteolysis) of the proximal femur. Nine of the complications were detected early (i.e. within the first six weeks after surgery), one was detected four years after the OP (osteolysis). All of the complications were detected in cases where the AC-EP was positioned in the joint's primary socket. The patients with complications associated with bone fractures (six femoral fractures and one sciatic bone fracture) had severe dysplasia prior to OP (group K234P). A history of previous OPs on a replaceable joint was noted in five of the bone fracture cases. Four proximal femur fractures were found during the primary THAs. In each of these cases, the range of OP was increased, and femoral osteosynthesis with cerclage wires was performed.

There were no cases of infection, dislocation, or aseptic loosening of the components during the follow-up period.

\section{DISCUSSION}

Many authors believe that placing the AC-EP at the anatomical site achieves a safe, stable primary fixation (Charnley, 1997; Linde, 1998)]. Our study affirmed the hypothesis that placing the AC-EP during THA in the secondary joint socket can yield good clinical and functional results in patients with dysplastic OA. A functional assessment of patients using Merle d'Aubigne-Postel's grading method and IGA showed no significant difference in results due to the placement of acetabular components in the primary or secondary socket. Placement of the AC-EP in the primary socket in cases of severe dysplasia significantly increased the risk of intraoperative complications. The majority of complications found in our study were intraoperative fractures of the proximal femur. All complications were found in patients with severe dysplasia (Crowe grades III and IV), and in all cases, AC-EPs were placed in the primary socket. The reasons for the fractures included a very narrow femoral canal and a difficult and forced reduction of the head of EP during OP. Two potential ways to reduce such complications are fixing the acetabular component in the secondary socket or by a femoral shortening and placing the acetabular component into the anatomic socket. Limitations of our study dealing only with early and mid-term follow-up results, and the number of participating patients. Additional studies of a longer duration and larger patient numbers are warranted.

In the literature, the most common early complication after THA in patients with hip dysplasia is dislocation (Paavilainen et al., 1993; Sanchez-Sotelo and Berry, 2001; Schöllner et al., 2003). Instability of the endoprosthesis is one of the most frequent causes for early intervention (Eftekhar, 1976; Lindberg et al., 1982; D’Angelo et al., 2008) Some authors state that increased rates of dislocations in dysplastic hips are associated with abnormal bone anatomy and altered muscle function (Sanchez-Sotelo et al., 2002). For the stability of the hip joint, offset and inclination angle of the acetabular cup are very important. An adequate offset is needed for proper tension in the abductor muscles. To gain increased offset, longer modular heads and lateralised stems should be used. Lewinnek et al reported that cups in $40^{\circ} \pm$ $10^{\circ}$ abduction fall into a safe zone (Lewinnek et al., 1978). In our study, the mean inclination angle of the acetabular component was $40.96^{\circ}$, but we note that abduction angles between $35^{\circ}$ and $55^{\circ}$ are tolerable. If signs of instability were noticed during OP, extended liners with $10^{\circ}$ - or $20^{\circ}$-lips must be used.

The surgical approach is also a risk factor. Many studies showed that THA using posterior approach has increased the risk of dislocation (Woo and Morrey, 1982; Masonis and Bourne, 2002) We found no dislocations during the follow-up period of 24 to 60 months, which is likely associated with our chosen approaches (5\% of which used a posterior approach).

Two incidents of nerve damage were identified in our study. In both cases, the cups were placed at the anatomical site. In one of them, the limb was elongated $3 \mathrm{~cm}$ in a patient with three previous childhood surgical interventions on the operable joint. Most authors in the literature state that limb lengthening by $4 \mathrm{~cm}$ can lead to overstretching soft tissues and damage to the sciatic nerve (Macheras et al., 2016; Lewallen, 1998). In cases where patients had previous OPs in the operable joint, the sciatic nerve may be involved in scar tissue, and, therefore, leg lengthening by $3 \mathrm{~cm}$ is too risky.

Radical anatomical and biomechanical reconstruction during THA can not only cause local complications such as fractures of the proximal femur or traction-type nerve injuries, but also distress of the whole musculoskeletal system. The lumbar spine, pelvis, and lower limbs have adapted to the changed anatomy of the dysplastic hip over the patient's lifetime. Many of these changes can become structural (fixed). Anatomical cup positioning in severe dysplasia cases can break down the developed compensatory balance of muscles and joints. In some cases, postoperative equal anatomical length of the lower extremities can result in a functional elongation of the operated leg. Therefore, for severe dysplasia cases, placement of the acetabular component in the secondary socket is a reasonable solution. We developed an original algorithm for the placement of the AC-EP in dysplastic hips during our study (Fig. 7). The requirements for cups placed in the secondary socket are the same as for those placed in the primary socket: adequate bone coverage (CEA 17 $^{\circ}$ ) and satisfactory offset.

In conclusion, the choice of placement of a cementless acetabular component during THA in a dysplastic hip depends on the grade of dysplasia, the expected elongation of the leg, and the degree of adequate bone coverage of acetabular cup. In severe dysplasia cases, placement of the acetabular component in the secondary socket can provide a good functional outcome for the patient and reduce the risk of complications. 


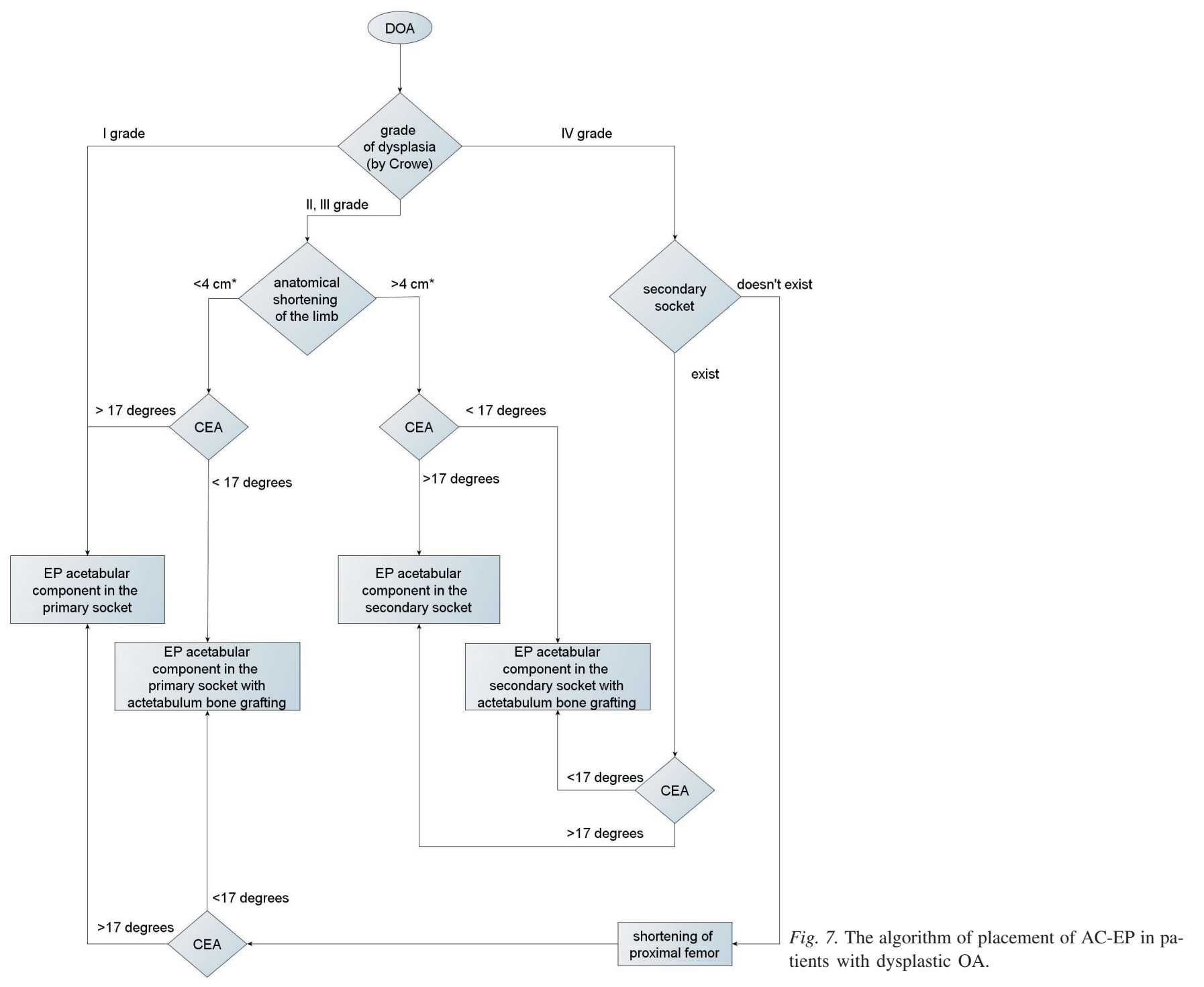

\section{CONFLICT OF INTEREST}

The authors report no conflict of interest.

\section{REFERENCES}

Bicanic, G., Delimar, D., Delimar, M., Pecina, M. (2009). Influence of the acetabular cup position on hip load during arthroplasty in hip dysplasia. Int. Orthop., 33, 397-402.

Bozic, K. J., Freiberg, A. A., Harris, W. H. (2004). The high hip center. Clin. Orthop. Relat. Res., 420, 101-105.

Charnley, J. (1979). Low Friction Arthroplasty of the Hip Theory and Practise. Springer, Berlin. 376 pp.

Crowe, J. F., Mani, V. J., Ranawat, C. S. (1979). Total hip replacement in congenital dislocation of the hip. J. Bone Joint Surg. Amer., 61, 15-23.

d'Aubigne, R. M., Postel, M. (1954). Functional results of hip arthroplasty with acrylic prosthesis. J. Bone Joint Surg. Amer., 36, 451-475.

D'Angelo, F., Murena, L., Zatti, G., Cherubino, P. (2008). The unstable total hip replacement. Indian J. Orthop., 42, 252-259.

Eftekhar, N. S. (1976). Dislocation and instability complicating low friction arthroplasty of the hip joint. Clin. Orthop. Relat. Res., (121), 120-125.

Harris, W. H. (1998). Reconstruction at a high hip center in acetabular revision surgery using a cementless acetabular component. Orthopedics, 21, 991-992.
Helkemaa, T., Hirvensalo, E., Huhtala, H., Remes, V. (2016). Patient injuries in primary total hip replacement. Acta Orthop., 87, 209-217.

Henrich, C., Engelmaier, F., Mehling, I., Sauer, U., Kirschner, S., Martell, J. M. (2007). Cementless acetabular reconstruction and structural bone-grafting in dysplastic hips. Surgical technique. J. Bone Joint Surg. Amer., 89, 54-67.

Kärrholm, J., Lindahl, H., Malchau, H., Mohaddes, M., Rogmark, C., Rolfson, O. (2016). The Swedish Hip Arthroplasty Register. Annual Report 2015. Ola Rolfson, Gothenburg. 172 pp.

Lewallen, D. G. (1998). Neurovascular injury associated with hip arthroplasty. Instr Course Lect., 47, 275-283.

Lewinnek, G. E., Lewis, J. L., Tarr, R., Compere, C. L., Zimmerman, J. R. (1978). Dislocation after total hip replacement arthroplasty. J. Bone Joint Surg. Amer., 60, 217-220.

Lindberg, H. O., Carlsson, A. S., Gentz, C. F., Pettersson, H. (1982). Recurrent and non-recurrent dislocation following total hip arthroplasty. Acta Orthop. Scand., 53, 947-952.

Linde, F., Jensen, J., Pilgaard, S. (1988). Charnley arthroplasty in osteoarthritis secondary to congenital dislocation or subluxation of the hip. Clin. Orthop. Relat. Res., 227, 164-171.

Lund, K. H., Tennansen, N. B. (1985). Hip replacement for congenital dislocation and dysplasia. Acta Orthop. Scand., 56, 464-468. 
Macheras, G. A., Christofilopoulos, P., Lepetsos, P., Leonidou, A. O., Anastasopoulos, P. P., Galanakos, S. P. (2016). Nerve injuries in total hip arthroplasty with a mini invasive anterior approach. Hip Int., 26, 338-343.

Masonis, J. L., Bourne, R. B. (2002). Surgical approach, abductor function, and total hip arthroplasty dislocation. Clin. Orthop. Relat. Res., 405, 46-53.

Montalti, M, Castagnini, F, Tassinari, E, Biondi, F, Toni, A. (2018). Cementless total hip arhroplasty in Crowe III and IV dysplasia: High hip center and modular necks. J. Arthroplasty, 33 (6), 1813-1819.

Paavilainen, T., Hoikka, V., Paavolainen, P. (1993). Cementless total hip arthroplasty for congenitally dislocated or dysplastic hips. Technique for replacement with a straight femoral component. Clin. Orthop. Relat. Res., (297), 71-81.

Park, M. S., Kim, K. H., Jeong, W. C. (2007). Transverse subtrochanteric shortening osteotomy in primary total hip arthroplasty for patients with severe hip developmental dysplasia. J. Arthroplasty, 22, 1031-1036.

Sanchez-Sotelo, J., Berry, D. J. (2001). Epidemiology of instability after total hip replacement. Orthop. Clin. North. Amer., 32, 543-552.
Sanchez-Sotelo, J., Berry, D. J., Trousdale, R. T., Cabanela, M. E. (2002). Surgical treatment of developmental dysplasia of the hip in adults: II arthroplasty options. J. Amer. Acad. Orthop. Surg., 10, 334-344.

Schöllner, C., Decking, J., Eckardt, A. (2003). The Artek cup for total hip replacement of dysplastic hip joints. Arch. Orthop. Trauma Surg., 123, 299-304.

Schwartz, M. H., Rozumalski, A. (2008). The gait deviation index: A new comprehensive index of gait pathology. Gait Posture, 28, 351-357.

Shen, B., Yang, I., Wang, L., Zhou, Z. K., Kang, P. D., Pei, F. X. (2009). Midterm results of hybrid total arthroplasty for the treatment of osteoarthritis secondary to developmental dysplasia of the hip - Chinese experience. J. Arthroplasty, 24, 1157-1163.

Symeonides, P. P., Poumaras, J., Petsatodes, G., Christoforides, J. (1997). Total hip arthroplasty with cement in neglected congenital dislocation of the hip. Curr. Orthop. Pract., 341, 55-61.

Woo, R. Y., Morrey, B. F. (1982). Dislocations after total hip arthroplasty. J. Bone Joint Surg. Amer., 64, 1295-1306.

Received 1 November 2018

Accepted in the final form 10 March 2019

\section{ENDOPROTĒZES ACETABULĀRĀ KOMPONENTA NOVIETOJUMA IZVĒLE DISPLASTISKĀ OSTEOARTRĪTA PACIENTIEM}

Gūžas locītavas edoprotezēšana pacientiem ar displāziju tiek uzskatīta par sarežğîtu ķirurǵisku operāciju. Daudzi ortopēdi uzskata, ka, operācijas laikā endoprotēzes acetabulāro komponentu ievietojot antomiskajā locītavas bedrītē, var sasniegt labāko rezultātu. Vienlaikus ir arī aizstāvji gūžas locītavas rotācijas centra augstākam novietojumam. Pētījumā mēs salīdzinājām edoprotezēšanas rezultātus saistībā ar endoprotēzes (EP) acetabulārā komponenta (AK) novietojumu, ar mērķi noteikt novietojumam piemērotāko vietu pacientiem ar dažādas pakāpes displastisku osteoartrītu (OA). Mūsu pētījumā tika iekḷauti 88 pacienti ar displastisku OA, kuriem triju gadu periodā tika veiktas 106 endoprotezēšanas operācijas ar bezcementa EP. Functionālos rezultātus novērtējām, izmantojot Merle Dubinjē (Merle d'Aubigne) un Posteḷa (Postel) novērtējuma skalu un instrumentālo gaitas analīzi (IGA). Lai salīdzinātu rezultātus pacientiem ar EP AK dažādu novietojumu, balstoties uz IGA datiem, tika aprēḳināts gaitas novirzes indekss. Funkcionālie rezultāti pacientiem saistībā ar EP AK novietojumu gan pēc Merle Dubinjē-Posteḷa novērtējuma skalas, gan IGA datiem neuzrādīja statistiski nozīmīgas atšķirības. Vairums komplikāciju tika konstatētas pacientiem ar izteiktu displāziju un EP AK novietojumu anatomiskajā locītavas bedrītē. Bezcementa EP AK optimālā novietojuma izvēle atkarīga gan no displāzijas smaguma pakāpes un nepieciešamā kājas pagarinājuma, gan arī no iespējas panākt pietiekošu EP AK nosegumu ar kaulu. Izteiktu displāziju gadījumos EP AK novietojums sekundārajā locītavas bedrītē nodrošina labu funkcionālo rezultātu, reizē mazinot potenciālo komplikāciju risku. 